\title{
"IT'S BRAW TO RIDE ROUND AND FOLLOW THE CAMP" \\ THE LINGUISTIC JOURNEY OF A SCOTS SONG, WITH AN IRISH SOLDIER, THROUGH SPACE AND TIME
}

\section{VALENTINA BOLD}

This article considers one song, "The Bonny Lass o Fyvie", in examples from Scotland, England, and North America. As it moves between language areas - from Scots language into English, Ulster-Scots and American English - there are significant shifts in audiences' understanding of its subtexts. The song was originally about women's rights to assert independence from men's desires, and the vulnerability of men in love. It ends as being about women's vulnerabilities, dislocated from its indigenous culture.

Keywords: Scots language, folksong, broadsides, tradition, folk revival, Aberdeenshire
$V$ članku je obravnavana ena pesem, "The Bonny Lass o Fyvie", v primerih s Škotske, iz Anglije in Severne Amerike. Ko se premika med razlicnimi jezikovnimi kodi-izškotskega jezika $v$ angleško, ulstrsko-škotsko in ameriško anglešcino prihaja do velikih premikov v tem, kako občinstvo razume njena sobesedila. Vsebina pesmi je bila najprej uveljavljanje pravic žensk, da dosežejo neodvisnost od moških želja, in o ranljivosti zaljubljenih moških. Konča pa se kot tematizacija ranljivostižensk, kojepesem odmaknjena od izvirne kulture. Ključne besede: škotski jezik, ljudska pesem, pesmi na letakih, tradicija, preporodna ljudska glasba, Aberdeenshire.

In this essay, I examine the story of one Scottish song, "The Bonie Lass of Fyvie" (Roud \#545) and its linguistic journey through time and space. The key language, in this discussion, is Scots: one of three native languages spoken in Scotland and a recognised European minority language (European Charter, 2021). The others are Scottish Gaelic and English, alongside the additional languages brought into the portfolio by new Scots and migrants. Scots has a rich spoken, as well as literary legacy, as well as a younger sister in Northern Ireland, Ulster-Scots (Robinson, 2018). Scots is a sister language to English, Scots (also known as Lallans, or the Scots Leid):

Scots originated with the tongue of the Angles who arrived in Scotland about AD 600, or 1,400 years ago. During the Middle Ages this language developed and grew apart from its sister tongue in England, until a distinct Scots language had evolved. At one time Scots was the national language of Scotland, spoken by Scottish kings, and was used to write the official records of the country. (Scots History, 2021)

I would like to invite you, if "The Bonnie Lass o Fyvie" is an unfamiliar song - or even if it is familiar - to begin by listening to Iona Fyfe's recent recording (Fyfe, 2021). It is long, detailed, and has a special poignancy, returning the song from its far-ranging travels (as will be discussed below) to its heartlands of North East Scotland. Fyfe learnt this song 
from Sam Kelly, who recorded it on his album Pretty Peggy (Kelly, 2017). Born in Huntly, Aberdeenshire, Fyfe performs the song in her own North East Scots - also known as "the Doric" - very much a living language in Scotland today (Millar, 2018). Singing, and speaking, in Scots language is at once an affirmative, natural and - in Scotland today - culturally assertive act, as has been recently argued (McKean, 2019).

Fyfe's language heritage is both distinctive and, in this context, very specifically resonates with this song set in Fyvie, in North East Scotland. North-East Scotland, significantly, is widely recognised as one of the most important regions for song in the United Kingdom. As David Buchan (one of the first modern scholars to write specifically about this area), noted:

Northeast balladry constitutes the richest regional tradition in Britain. The warrant for this assertion lies in both the quantity and the quality of the area's ballads: the tradition has more recorded ballads than any other and it includes what good authority has judged the "best ballads". (Buchan, 1972: 4)

Whilst there are other areas of Scotland which could vie for this title (Bold, 2009a). It is within this context, of a rich, regional, Northern song heritage, that "The Bonnie Lass o Fyvie", and its various performances, should be placed and appreciated.

"The Bonnie Lass o Fyvie", in Fyfe's - and other - versions, has endured, most probably, because of its simple, satisfying story, with an emphatic ending, coupled with a light, engaging air. A beautiful girl, usually called Peggy, is desired by an Irish soldier, usually a dragoon, who is passing through her homelands. He falls in love, she rejects him, he has orders and has to leave, and he dies for love, soon after marching away. The episode is short, progresses swiftly, and is usually resolved without much in the way of explicit commentary.

It is an unusual storyline, in several respects. Many songs, of course, focus on the experiences of central female characters; it has been estimated that over $30 \%$ of Scottish ballads, for instance, are "centrally concerned with women"; intriguingly many of these, like the "Bonny Lass o Fyvie" feature a "heroically defiant female" (Cowan, 2000: 95-98). In Scots songs, as elsewhere, though, women in love often die ("Little Musgrave", Child \#81, Roud \#52), want to die for love ("The Unquiet Grave”, Child \#78, Roud \#51), or are victims of lustful, vindictive men ("The Bonnie House o Airlie”, Child \#199, Roud \#794). Women can certainly show resilience in the face of abandonment ("Mormond Braes", Roud \#2171). However, usually, their reputation is irrevocably damaged, after a man has his way with them ("The Irish Boy"), or her brothers murder him in a horrific honour killing ("Dowie Dens o Yarrow", Child \#214, Roud \#13). It is rarely the other way around.

This does seem to be an unusual song, above all, in giving a girl the right to choose her path in love, and to choose to remain unmarried, rather than to accept a marriage proposal. We do learn, in many versions, that the girl is not prepared to sacrifice her life at home, or her reputation, for "marriage". Perhaps, the audience is meant to extrapolate that soldiers do not actually mean marriage when this is offered. As one North East Scottish 
writer put it the heroine seems, in effect, to have had a "lucky escape" (Cheyne, 2002). However, paradoxically, the soldier in this song often does appear to have been genuine in offering his hand to the Bonnie Lass.

The song is rather short on detail. We are not told anything about why the soldier is in Fyvie. Some singers take this as evidence he is from an occupying force, as he is clearly not local. However, there is no real (historical) reason for such a force to be passing through the Fyvie area. There was a Battle of Fyvie in 1644, when the Duke of Montrose's forces clashed with the Covenanting army of the Marquis of Argyll, and both forces ultimately withdrew (HESI, 2021). But there is no evidence that Irish dragoons were involved in that encounter. It is possible there are folk memories of soldiers marching through Aberdeenshire to the military base at Fort George (Canmore, 2021). However, such specificity is not there - or needed for the song to work imaginatively. There is a lot unsaid, then, within the text about the precise situation of the central couple, and the context for their involvement.

\section{THE DISCUSSION}

In what now follows, I will focus on a small set of versions, selected as fairly typical of the multiple versions of this song; in discussing traditional song it has been said that "only a small sample - like a bucketful from an ocean" is ever accessible; this seems particularly true in the case of "The Bonny Lass o Fyvie" (Lyle, 1997: 10). Here, starting with broadside examples, I will look at a variety of recorded performances by female and male singers - an additional factor in the song's interpretation - whose linguistic backgrounds are in Scots or varieties of English. Most are in Scots language: three from North-East Scotland including John Strachan (1951), The Old Blind Dogs (1992) and Iona Fyfe (2020). Two are from Ireland: the Clancy Brothers with Tommy Makem (1961) and the Dubliners (1962). Two, which I will mention but not discuss in detail, are American: Bob Dylan (1962) and Joan Baez (1963). Examining these together demonstrates shifts in the way the song is performed and received, and to show how its migration has subtly, but vitally, altered its meaning.

Ultimately, in discussing "The Bonnie Lass o Fyvie”, I want to suggest that language shifts, during a song's lifespan, can lead to changes in the way a song is understood, both for those who perform it and those who listen. These, ultimately, can lead to shifts in its story and meaning. This process, in terms of song analysis, too, may have wider significance in understanding how language changes affect a song's core meanings. Mainly, my choice of examples is in Scots language; there are also some instances of Ulster-Scots (Scots' Northern Irish sister), some English specimens, and one Scottish Gaelic word. 


\section{A SONG OF MANY NAMES}

"The Bonnie Lass o Fyvie", in its various incarnations, has many names, including: "The Bonny Lass o Fife-y”, "Maid of Fife-E-O”, "Bonnie Streets of Fife-y”, "Bonny Lass o Derby”, "Bonny Lass of Derry", "Pretty Peggy of Derby", "Sweet Peggy O", "Pretty Peggy", "Bonny Barbara O”, "Pretty Fanny O”, "Pretty Peggy O", "Peggy-O”, "Fennario' and 'Frenario". Not surprisingly, many of these are from the part of Scotland where Fyvie itself is located, in Aberdeenshire and Scotland's North-East corner; this is, incidentally, a song location elsewhere - it also figures in the ballad of tragic love, "Mill o Tifty's Annie" (Child \#233, Roud \#98)', set “in the neighbourhood of Fyvie”.

There are twenty-three texts for "The Bonny Lass o Fyvie" in the North-East Scottish Greig-Duncan collection alone, mainly as the "Bonny Lass o Fyvie" or "Pretty Peggy O", with the odd variant like "Pretty Barbara O" (Greig-Duncan, 1981-2002). The song was first recorded by Willie Kemp, in 1931 (Kemp, 1931). There are early cylinder recordings, too, by Bell Duncan and Elizabeth Robb; these were made in the 1930s, and now in the James Madison Carpenter collection (Duncan, N.d.; Robb, N.d.). Probably the best known, early version, though was that recorded by John Strachan, in 1951, as I will address presently (Strachan, 2002). “The Bonnie Lass” was subsequently recorded by Scottish artists including the Corries and Gaberlunzie; the Irish Rovers, and American singers including Joan Baez, Simon and Garfunkel and the Grateful Dead.

\section{RESILIENT ELEMENTS}

"The Bonnie Lass of Fyvie" (Roud \#545), is set in, and most probably originated in, the North East of Scotland, localised in the lands around Fyvie Castle. It seems to have undertaken a complex linguistic journey. I will now trace its journey from early versions in Scots language, as it shifted, over space and time, moving outwards to England, Ireland and North America.

Some of the song elements remain in almost every version. They include particularly memorable or poetic phrases: for instance, most make reference to a "troop" of "Irish dragoons". Invariably, too, there's the image of the girl running down stairs throwing back, or tying back, or otherwise displaying her beautiful yellow hair. Then there are what I consider to be 'concept' phrases - linguistic elements that convey the storyline of the song, often through dialogue. The suitor, always a "captain", offers the girl incentives to marry him. It usually is marriage rather than a dalliance - although there are a few examples when a dalliance is all that is on offer. Incentives added to betrothal can include the excitement of following a camp, or of material goods, like clothes and jewels.

The place names are fluid - Fyvey itself can be Fifie, or Derby or Derry, as is so often the case for migratory songs and stories (Christiansen, 1958). The 'difficult' place 
names, if you've not been there and so have not heard them before, like Bethelnie or the "howe" (hollow, low-lying ground) of Auchterless tend to be lost or adapted. There is, for instance, the change to "Auchterglass" in at least one Irish version. Auchterless / Auchterglass, perhaps, is retained because it has a nice full sound, or ring to it, for the singer and audience. The captain is always told to march, usually by a Colonel, or colo-nel as it can be pronounced (presumably because, during some transmission processes through print the word, in an unfamiliar spelling, was picked up by someone without knowledge of how to pronounce it). The captain, too, always dies - although, in some later, American versions, the girl is unhappy - which she clearly is not in the best-known Scottish, English and Irish versions.

"The Bonnie Lass o Fyvie" is a song, incidentally, which seems to particularly appeal to male singers - maybe there is something about the good sense of Scottish women being highlighted. There are a few versions by women, including a sympathetic Karine Polwart, with her former band Malinky, but the predominance of male singers for this song is intriguing, although not part of my discussion here.

\section{“THE CAPTAIN HE CRIED, “TARRY O”: THE OLD BLIND DOGS}

The first version I would like to consider in detail is one sung by the North East Scottish band, "The Old Blind Dogs". The singer is Ian Benzie; the recording from the 1992 release New Tricks (Old Blind Dogs, 1992). The words follow and, to help those readers unfamiliar with Scots language, I have put the words, in its regional dialect of North East Scots, alongside glosses into English:

Well, there once was a troop o Irish dragoons

Cam marchin doon through Fyvie $O$

Captain's fan in love wi an affa bonnie quine

fan: fallen, affa bonnie

Oh the name that she had was pretty Peggy $O$.

quine: very pretty girl

"Oh come runnin doon yir stairs, pretty Peggy, my dear

doon: down, yir: your

Come runnin doon yir stairs, pretty Peggy $O$

Come runnin doon yir stairs, tie back yir yella hair

Tak a last fareweel tae yir daddie $O$

yella: yellow

fareweel: farewell

Well, it's braw, it's braw a captain's lady for tae be

braw: fine, for to be: to be

It's braw tae be a captain's lady $O$

Braw tae ride and rant, an tae follow wi the camp

$O h$ an march when yer captain he is ready $O$ 
Now the colonel, he cried, "Mount, boys, mount, boys, mount"

$O h$ the captain, he cried, "Tarry $O$

Tarry for a while, for anither day or twa

anither: another, twa: two

Just tae see if this bonnie lass will marry $O$ "

Oh but syne e'er we cam' up tae Bethelnie

Wir captain we had for tae carry $O$

toon toon: farm (fermtoun)

wir: our

An'syne e'er we cam up tae bonnie Aberdeen

Oh wir captain we had for tae bury $O$.

Well, there's monies a bonnie lassie in the howe o"Auchterless

monie: many, howe: hollow

There's monies a bonnie dame in the Gairy $O$

There"s monies a bonnie Jean in the toon o' Aberdeen

Gairy: Garioch

toon: town

But the flower o' them a' bides in Fyvie $O$

floor: flower, bides: lives

Well, it's green grow the birks on bonnie Ythan side

birks: birch trees

An low lie the Lowlands o Fyvie O

The captain's name was Ned, an he died for a maid

Oh he died for the sodger lass o' Fyvie

lowlands: low lying lands

sodger: soldier

Aye, there once was a troop o Irish dragoons

Cam marchin doon through Fyvie $O$

And the captain's fan in love wi an affa bonnie quine

Oh the name that she had was pretty Peggy $O$

FYVAEEEEEEEEEE! O.

As performed by the Old Blind Dogs, this is a very spirited song, with a lively air. The tune itself is popular for pipe bands, perhaps because of the song's military associations and resonances; there's a nice recording, for instance, by the Royal Scots Dragoon Guards - even if they are not Irish dragoons per se (Royal Scots Dragoon Guards, 2008).

Aspects in the Old Blind Dogs' version that appeal to me and, I am sure, to audiences, include, for a start, the language. This is conversational North East Scots, the local dialect of the Scots language. I also appreciate the assertive performance style of that final "Fyvvvieee-O". Both of these dimensions bring out the messages and meaning I have just outlined, explicitly. 


\section{BROADSIDES}

The earliest evidence in of "The Bonny Lass o Fyvie" is to be found in broadsides and, intriguingly, many of these were printed in England. It may be that the song migrated south at an early stage of its life and was adopted, and acclimatised, to local placenames in England. The English fascination with Scottish song has been well documented (Fiske, 1983). Alternatively, it has been suggested that it may originated in England and become acclimatised to Scottish settings (Olson, 2010). Whichever scenario is true - and difficult to verify - by the late nineteenth century the song was certainly perceived to be a North East Scottish text, by Scots, as can be seen in the multiple Greig-Duncan examples, mentioned above. This became an important part of its identity - as often, in songs popular in specific communities, for a content which could be seen as having "expressed values shared by the community" (Post, 2004: 474): in this instance, specifically, the value placed on a young woman's honour, and her right to protect it.

Whatever its origin, "The Bonnie Lass” was first recorded in the nineteenth century as a broadside form, and those extant are, as just mentioned, primarily English. In these, the place is relocated to (or began in) Derby or, sometimes, perhaps through a typographical error, to Derry. One broadside by the London printer J. Pitts, now in the Bodleian collection, for instance, uses Derry in the title, but reverts to Derby in the song ("Pretty Peggy of Derry" c. 1819-1844). Here is a transcript from a second Pitts example, printed in London, like the one just cited, between 1819 and 1844. It is nearly identical to the example just cited, bar the use of different woodcut, heading image, and the omission of exclamation marks after each 'Oh' which were included in the previous example cited: ${ }^{1}$

\section{PRETTY PEGGY OF DERBY}

There was a regiment of Irish dragoons,

They were all marching to Derby $O$,

The captain fell in love with a young chambermaid,

And her name it was pretty Peggy $O$,

Oh come down stairs pretty Peggy $O$,

Oh come down stairs pretty Peggy $O$,

Oh come down stairs and comb back your hair,

And take the last farewell of your darling $O$.

I'll tell you now as I told you before,

And why should you leave me O teaze me no more,

1 Pretty Peggy of Derby. N.d. Firth c.14 (186). http://ballads.bodleian.ox.ac.uk/view/sheet/3565. 
What will your mammy think when she hears you are sick, And hautboys are playing before you go.

A soldier's wife I never will be,

And a soldier shall never lay in bed with me

For I will make him stand with hat in his hand,

When he stands in presence of my company,

Then spoke his brother a stout young man

A valiant soldier as he was,

Saying if you shall not go we shall get sweethearts anew,

When we come to Kilkenny $O$.

When we come to the water that runs so clear,

That joins the town of Kilkenny $O$,

The captain sighed and said we are many miles away,

Here's a health to the pretty girl of Derby $O$.

When they came to the town the very last town,

The town they call Kilkenny $O$,

His name was captain Wade he died for a maid,

And he died for the pretty girl of Derby $O$.

"Pretty Peggy of Derby", has some - but not all - of the characteristics of the song as performed by the Old Blind Dogs, a hundred and more years later. For instance, the Irish dragoons are there, although as a "regiment" rather than a troop. The girl is Pretty Peggy but, in the cheap print version she is given a job. Perhaps, here, to appeal to a London audience, more familiar with town life than country, she is a "young chambermaid". There are print-style elements "hautboys" play in front of Peggy, and she is told not to "tease" the boy. Her response is more explicit too - she will not have sex with a soldier, and she'll show him some manners - "I will make him stand with hat in his hand".

There are extra characters too - a brother of the Captain - and, rather than the suitor having the friendly name of "Ned" - which he is in most modern versions - the nineteenth century print captain is called Ward. This version is very firmly in English language, with English idioms. I would suggest it loses some of its character because of this. It does, though, retain the charming image of Peggy running down the stairs, here combing her yellow hair rather than tossing it back, coquettishly, as she does in Scots versions. 


\section{JOHN STRACHAN}

To come back to Scotland again, I would like to bring in the 1951 recording of the song, by John Strachan (2002):

There was a troop o Irish dragoon,

Come marchin doon through Fyvie $O$,

And the Captain's fa'n in love wi a very pretty maid, fa'n: fallen

And her name was called pretty Peggy $O$.

Oh come doon the stair, pretty Peggy my dear,

Oh come doon the stair, pretty Peggy $O$,

Oh come doon the stair, kame oot yer yalla hair kame oot: comb out, yalla: yellow

Take a last farewell o yir daddy $O$.

$O$ A'll gie ye ribbons, an A'll gie ye rings,

An A'll gie ye a necklace o amber $O$,

A'll buy ye silken goons tae rowe ye roon an roon

If ye'll follow me o your wanderings $O$.

O mount boys, mount," the Colonel he cried,

"O tarry, O tarry", cried the Captain $O$,

" $O$ tarry, $O$ tarry, anither day or twa,

anither: another

Ere I see if this bonnie lass will marry $O$ "

And lang or they come tae ald Meldrum toon,

They hid their Captain tae cairy $O$,

gie: give

goons: gowns, rowe: roll roon: round

And lang or they won in tae Aiberdeen

ald: old

They had their Captain tae bury $O$.

cairy: carry

tae: to

But that's a good yin, a fine tune! A'm affa pleased ye like that yin! affa: awfully

This is similar in feel, although unaccompanied, to the Old Blind Dogs version, but you can see from the text that the Scots language elements, which seem to have escaped the influence of the English broadsides, are very much to the fore. Here, there is a little more than the Old Blind Dogs later give - the girl is offered various incentives to marriage, like ribbons, rings and an amber necklace.

She is also given what I would call a Scots song offer. There's a convention, in lyric songs - and mildly bawdy songs (Bold, 2009b) to offer to "row" or roll a Scottish girl - see, Isobel Pagan's "Ca the Yowes to the Knowes" (Roud \#857): "He row'd me sweetly in his 
plaid, / And he ca'd me his dearie", or Robert Burns' "As I came o'er the Cairney Mount", known in oral tradition as "The Hielan Laddie" (Roud \#5524). Enveloping a Scottish girl, in the context of song, is usually done in a plaid, or cloak. In "The Bonny Lass o Fyvie", instead of coarse woollen cloth, the girl is offered silken gowns: "tae rowe ye roon an roon". There are also additional North East Scottish place-names: Ald (Old) Meldrum toon (town). For instance. Strachan's recording also includes some field-recorded comments on the text: "that's a good yin, that's a fine tune" (Strachan, 2002).

I am not sure how much traction, or influence, that recording had but I do know that "The Bonnie Lass o Fyvie" played a significant role in the Scottish folk song revival of the 1950s and onwards, both in Scotland and in Ireland. I have it on good authority, and thank Jim Carroll for this, that the song came to Ireland through Luke Kelly's association with Ewan MacColl, and MacColl's performance of the song. Carroll told me that "the only traditional version of 'Fyvie' found in Ireland was from Thomas Moran from County Leitrim - he had a large repertoire of Anglo Scots and Irish songs"; but MacColl's was the one that became "popular" (Carroll, 2020).

\section{“IT'S BRAW TO BE A CAPTAIN'S LADY O”: EWAN MACCOLL AND PEGGY SEEGER}

MacColl's 1960 recording, with Peggy Seeger, introduces some elements from MacColl's familiar varieties of Scots (MacColl, Seeger, 1960). "Wir" for our, for instance, is something more associated with West coast Scots, rather than the East coast linguistic spectrum of Aberdeenshire, like the versions examined so far. Here is a transcript of this version:

It was a troop o Irish dragoons,

Come merchin doon through Fyvie-O

merchin: marching

And the Captain's fa'n love with a very bonnie lass

And her name it was ca'd pretty Peggy $O$.

There's many a bonnie lass in the howe o Auchterless,

There's many a bonnie lassie in the Gairy $O$,

There's many a bonnie Jean in the streets o Aiberdeen,

But the flooer o them a is in Fyvie $O$.

flooer: flower

O cam doon the stair, pretty Peggy my dear,

Cam doon the stair, Pretty Peggy $O$

$O$ cam doon the stair, comb back yer yella hair,

Tak a last farewell o your daddy o." 
"It's braw, aye, it's braw a Captain's lady fir to be,

It's braw to be a Captain's lady $O$,

It's braw to ride and rant, and tae follow wi the camp,

And to merch when you're Captain he is ready $O$,

'It's A'll gie you ribbons, love, and A'll gie you rings,

A'll gie ye a necklace o aimber $o$,

I'll gie ye siller petticoats, wi floonces tae the knee,

Gin ye'll convoy me doon tae ma chaimber $O$ "

"Fit wid yir minnie think, if she heard the guineas clink. minnie: mother And the hautboys playin afore ye o"

"Little would ma mammy think, though she heard the guineas clink,

If $A$ went and followed a sodger $O$ "

"A sodger's wife A never will be,

$A$ sodger shall never enjoy me $O$,

I never do intend tae gang tae a foreign land.

gang: go

And A never will marry a soldier o."

The Colonel cries "Mount. Mount, boys, mount!

But wir Captain he cries "Tarry $O$.

wir: our

Now tarry for a while, jist anither day or twa

twa: two

Till I see if this bonnie lass will merry O.”

"A'll drink nae mair o yer guid claret wine,

guid: good

A'll drink nae mair o yer glasses $o$,

The morn is the day that I maun march away,

the morn: tomorrow

So adieu to yir Fyvie lassies o."

It's early next day that we merched awa,

And $O$ but the Captain he was sorry $O$,

The drums they did beat ower the bonnie braes o Gight,

And the band played the bonnie lieus o Fyvie o.

It's lang e'er we won to Auld Meldrum toon,

lang e're: long before

We had wir Captain we had to carry $O$,

And lang e'er we won into bonnie Aberdeen,

We got wir captain to bury $O$. 
Oh green grow the birks upon bonny Ythanside, birks: birch trees

And low lie the Lowlands o Fyvie-O,

Our captain's name was Ned, he died for a maid,

He died for the chambermaid o Fyvie-O

\section{"THE TOWN O AUCHTERGLASS": THE CLANCY BROTHERS WITH TOMMY MAKEM}

The Clancy brothers and Tommy Makem sing a version which definitely owes a debt to MacColl (Clancys, Makem, 1965). You can see they learnt it by sound, not reading, in their use, for instance, of "Auchterglass", which sounds more Irish, as a 'heard' version of Auchterless; similarly "the Cheery O" is a misheard "Gairy":

There once was a troop of Irish dragoons,

Come marchin down through Fyvie-O

And the Captain's fell in love with a very bonnie lass

Her name it was called pretty Peggy $O$.

O there's many a bonnie lass in the town o Auchterglass,

There's many a bonnie lassie in the Cheery $O$

There's many a bonnie Jean in the streets of Aberdeen,

And the flower o them a lives in Fifie $O$.

"Come down the stairs, pretty Peggy my dear,

Come down the stairs, Pretty Peggy O

Come down the stairs, comb back yer yella hair,

Bid a long farewell to your mammy o."

"I never did intend a soldier's lady for to be,

I never will marry a soldier o

I never did intend to gang to a foreign land.

gang: go

And I never will marry a soldier o."

The Colonel he cried, "mount. Mount, boys, mount!

The captain he cried, "Tarry $O$.

"Now tarry for a while, for another day or twa

twa: two

Till I see if the bonnie lass will marry O.

Well lang e'er we came to the town o Auchterglass 
Our Captain we had to carry $O$,

And lang e'er we came to the streets of Aberdeen,

We had our captain to bury $O$.

Green grow the birks on bonny Ythanside,

birks: birch trees

And low the Lowlands o Fifie-O,

Our captain's name was Ned and he died for a maid,

He died for the chambermaid o Fyfie 0 .

O there's many a bonnie lass in the town o Auchterglass,

There's many a bonnie lassie $i$ the Cheery $O$

There's many a bonnie Jean in the streets o Aberdeen,

But the flower o them a is in Fyvie $O$.

This version is a fascinating linguistic hybrid. While the Clancys were from County Tipperary, in Munster, in the South West of Ireland; Makem is from County Armagh, in the North. Ulster-Scots elements are, in the process, introduced into the song, in passages where the singers perform in dialogue. There are traces of Ulster Scots grammar: "the Captain's fell in love", for instance, as well as in the language: "gang" for go.

\section{“PRETTY PEGGY MO GHRÀIDH”: THE DUBLINERS}

Another notable Irish performance of the song is by the Dubliners. They keep the broadside 'chambermaid' and the unusual word, "Auchteress". They go one step further than the Clancy brothers, too, by introducing an element of Scots Gaelic, borrowed from another song, "A Pheigi, A Ghraidh" ("Peggy, My Beloved”); a transcription follows:

Well there once was a troop of Irish dragoons,

And came a marchin on Fife e'o,

Their captain fell in love with a very bonnie lass

Her name it was called pretty Peggy $O$.

"Well come down the stairs, pretty Peggy mo ghràidh

mo ghràidh: my darling, love

Come down the stairs, Pretty Peggy $O$

Come down the stairs, my dear, pull back yer yellow hair,

Bid a long farewell tae your mammy o."

"I never did intend a soldier's lady for to be,

I never will marry a soldier $o$ 
I never did intend to go to a foreign land.

I never will marry a soldier $0 . "$

Well the Col-on-el he cried, "mount boys, mount!

The captain he cried, "Tarry $O$.

"We'll tarry for a while, for another day or tway,

We'll see if the bonnie lass will marry O."

Long e'er we reached the town o Auchterless

We had our captain to carry $O$,

And long e'er we reached the streets of Aberdeen,

We had our captain to bury $O$.

Well green grow the bykes on bonny Ythanside,

bykes: corn

And low the Lowlands o Fife e'o

Well our captain's name was Ned and he died for a maid,

He died for the chambermaid o Fife e'o.

I feel that the nuances of interpretation - reinforced by the language shifts - here give the song a slightly different meaning. Where in North East Scots, the lass is a "quine" (young woman); in the Scots of Ewan MacColl and in Irish versions she a "lass"; in Scots and Irish "bonny" (as will be seen, later in English / American "pretty").

These superficial differences mask deeper, cultural ones. In the Scots versions, the girl is in the right, her rejection a proto-feminist act echoed by her loose hair - which the soldier wants her to tie. In a profound sense, she says no to the supposition that she is available. She is implicitly stating that she rejects the military man's establishment view of herself as the 'charming eccentric Other' which the dominant culture so often perceives the minority culture to epitomise (Calin, 2000: 6).

Perhaps it is taking matters too far to perceive this small, simple song as a minority culture's assertion of Self over the assumed characteristics of the Other. Certainly and, arguably, enduringly, after the 1707 Union of the Parliaments - "the defining moment (in historical terms) for the structures of Union and fragmentation" (Manning, 2002: 11) - Scots were unequivocally seen as both Other and Provincial in a British context. In this context, there are analogies with the "blatantly sexual and somewhat predatory stare" that has been identified in white portrayals of people of colour, internationally and into the twentieth century and beyond (Carby, 1995: 188). This gaze is at once entitled and reprehensible and, perhaps, is implicitly the starting point for this song's Captain's courtship. Seen like this, "The Bonny Lass o Fyvie" primarily tells a story, as skilfully as a folk tale, in a way that encourages the audience to fill in the missing pieces of the plotline. It has been observed that Scots folk tales, in particular, are characterised by 'humour and 
strong dramatic action' (Smith, 2001: 61). Like many tales without music, "The Bonny Lass o Fyvie" is at once assertive, knowing, and daring.

In Irish versions, as here, I get more of a sense that the Bonny Lass is provocative, rejecting true love and leading to a young hero's death. There are less cultural nuances, and more straightforward storytelling. "Our" captain is the focus rather than "the" captain of the Scots song. In a sense, she has lost the very aspects of character that make the Bonny Lass memorable in Scots' versions of the song - the implicit "herstoriography" (Beiner, 2003), associated with this girl who rejects marriage, and refuses to leave her country, is replaced with conventional romance. In America, in contrast, the Captain (as in Scotland) is 'othered' again, a member of an assumed occupying force - which perhaps makes more sense in that specific cultural (and historical) context. There are, moreover, significant shifts, too, in the song's journey - in language as well as plot - to the USA.

\section{FROM SCOTLAND TO LOUISIANA}

"The Bonnie Lass o Fyvie" migrated to North America at least from the nineteenth century onwards; it is referenced in English Folksongs from the Southern Appalachians, for example (Campbell, Sharp, 1917: 371). There, it is asserted that this is an English song, set to the air "Pretty Girl of Derby O", erroneously identified as an Irish tune by Thomas Moore, and with Fyvie 'substituted' for Derby by Gavin Greig.

Whatever the precise provenance (and local patriotisms are, perhaps a factor in how this story is interpreted) Bob Dylan's version, with a nod and a wink to the "Fyvie" of the title, presents the location as an imagined place: "I've been around this whole country / But I never yet found Fenneario" (Dylan, 1962). Dylan's version is a skilful embroidery on the "Bonnie Lass o Fyvie" storyline. It retains some traditional elements and embroiders the storyline, skilfully. Some typical elements are retained: Dylan's Peggy runs down the stairs, yellow-haired and pretty; the hero, a captain here, dies for love. However, this is clearly a song re-located to America, featuring a lieutenant who is a rodeo-rider in Texas, and a lover buried in Louisiana.

Joan Baez goes even further, developing Dylan's 'Fenneario' into 'Fennario'. Peggy still skips downstairs to meet her man, William. However, this piece hints at a woman defending her honour, with threats to despoil her home and the women around her: "If ever I return all your cities I will burn, / Destroying all the ladies in the are-o" (Baez, 1963). Baez, in this respect, perhaps understands the subtext of the song better than other, lighter interpreters of the song. Her girl is asserting her rights in the face of real threats, rather than merely an invitation to marriage. 


\section{CONCLUSION}

In its journey through space and time, it seems, then, that "The Bonny Lass o Fyvie" becomes darker and deeper. In the process, though, it loses its links with the language and culture that originated, or accrued, around it - and the folklore, arguably, of the right of women to assert themselves, and the vulnerability of men who are rejected in love. It introduces generic, but not particularly poetic, elements like carriages and rides (in its American incarnations), over the economy and vividness of the first versions - particularly those in Scots. In the journey, the song, I think, loses some of its relevance, particularly for those who know Fyvie (Derby or Derry, too) as a special place, and a place whose legacy is integrally linked to Scots language, idioms and culture. The eponymous girl, I think, most importantly, shifts from heroine (in Scots) to villain; the storyline moves from lightness to tragedy and the song changes for its new audiences, irrevocably.

\section{REFERENCES}

Baez, Joan. 1963. Fennario. Joan Baez in Concert Part 2. New York: Vanguard. VSD 21-23. https://youtu. be/tWWOGBNRC5c.

Beiner, Guy. 2003. Oral Herstoriography. In Ireland (Ulster) Scotland: Concepts, Contexts, Comparisons, eds. Edna Longley, Eamonn Hughes and Des O’Rawe, 86-93. Belfast: QUB Press.

Bold, Valentina. 2009a. "I wish I was whaur Helen lies": Collection, Community and Regeneration in Modern South West Scotland. Markings 28: 57-68.

Bold, Valentina. 2009b. Introduction. In Robert Burns' Merry Muses of Caledonia, eds. Valentina Bold et al. Edinburgh: Luath.

Buchan, David. 1972. The Ballad and the Folk. London: Routledge, Kegan Paul.

Calin, William. 2000. Minority Literatures and Modernism: Scots, Breton and Occitan, 1920-1990. Toronto: University of Toronto Press.

Campbell, Olive Arnold, and Cecil James Sharp. 1917. English Folk Songs from the Southern Appalachians. New York: G. P. Putnam.

Canmore. 2021. Fort George. www.canmore.org.uk/site/174512/fort-george.

Carby, Hazel V. 1995. National Nightmares: The Liberal Bourgeoisie and Racial Anxiety. In Racial and Ethnic Identity: Psychological Development and Creative Expression, eds. Herbert W. Harris, Howard C. Blue and Ezra E. H. Griffith, 173-192. London: Routledge.

Carroll, Jim. 2020. Personal communication.

Cheyne, Sandy. 2002. Lucky Escape for Fyvie’s Bonnie Lass. The Leopard, September.

Child = Child Ballads: A Complete List. https://contemplator.com/child/cmpltchl.html.

Christiansen, Reidar Thoralf. 1958. The Migratory Legends. Helsinki: Suomalainen Tiedeakademia.

Clancy Brothers, The, and Tommy Makem. 1965. The Maid of Fife. Recorded Live in Ireland. New York: Columbia. PCT 9065. https://youtu.be/k8garPXFIgg. 
Cowan, Edward J. 2000. Sex and Violence in the Scottish Ballads. In The Ballad in Scottish History, ed. Edward J. Cowan. Phantassie, East Linton: Tuckwell.

Dubliners, The. 1964. Maid of Fife e’o. Irish Folk Night. New York: Decca. LK 4633 LP. https://youtu.be/ L28Cr85yRJc.

Duncan, Bell. N.d. The Bonnie Lass o Fyvie. James Madison Carpenter Collection. Washington: American Folklife Center 1972/001, Cylinder 114 01:13). http://www.dhi.ac.uk/carpenter.

Dylan, Bob, 1962. Pretty Peggy-O. Bob Dylan. New York: Columbia. CS 8579. www.bobdylan.com/songs/ pretty-peggy-o.

European Charter, The. 2021. www.scotslanguage.com/articles/node/id/250f.

Fiske, Roger. 1983. Scotland in Music: A European Enthusiasm. Cambridge: Cambridge University Press.

Fyfe, Iona. 2021. Bonnie Lass of Fyvie. https://ionafyfe.bandcamp.com/track/bonnie-lass-of-fyvie.

Greig-Duncan. 1981-2002. In The Greig-Duncan Folksong Collection, eds. Patrick Shuldham-Shaw and Emily B. Lyle. Aberdeen: Aberdeen University Press. University Press.

HESI. 2021. Historic Environment Scotland Inventory. www.portal.historicenvironmentscot.designation/ BTL22.

Kelly, Sam. 2017. Pretty Peggy. London: Navigator. B073VZRDD2.

Kemp, Willie. 1931. The Miles and the Road to Dundee / The Bonnie Lass o Fyvie. Ellon, Aberdeenshire: Beltona. BL 1695.

Lyle, Emily, ed. 1997. Scottish Ballads. Edinburgh: Canongate Press.

MacColl, Ewan, and Peggy Seeger. 1960. The Bonny Lass of Fyvie. Popular Scottish (Folkways Records, 1960) FW 8757. https://youtu.be/K837d7-0hRc.

Malinky. 2000. The Bonny Lass of Fyvie. Last Leaves (2000), Greentrax CDTRAX 190. https://youtu. be/PMZmI-Hn_DU.

Manning, Susan. 2002. Fragments of Union: Making Connections in Scottish and American Writing New York: Palgrave.

McKean, Tom. 2019. Speaking from the Heart in Doric: The Language of Home and Family. The Press and Journal. 5. https://www.pressandjournal.co.uk/fp/lifestyle-columnists/1904993/ tom-mckean-speaking-from-the-heart-in-doric-the-language-of-home-and-family.

Millar, Robert McColl. 2018. Modern Scots: An Analytical Survey. Edinburgh: Edinburgh University Press.

Old Blind Dogs. 1992. The Bonnie Lass O’ Fyvie. New Tricks (Lochshore), CDLOC 1068. https://youtu. be/3AlLt_iTk0.

Olson, Ian A. 2010. “The Bonny Lass o' Fyvie” or "Pretty Peggy of Derby”? Review of Scottish Culture 22: $150-163$.

Post, Jennifer C. 2004. Clyde Colvill: Reconstructing a Community Tradition. In Folk Song: Tradition, Revival, and Re-Creation, eds. Ian Russell and David Atkinson, 463-475. Aberdeen: The Elphinstone Institute.

Pretty Peggy of Derry. c. 1819-44. Harding B25 (1565). Harding B 25(1565). http://ballads.bodleian.ox.ac. $\mathrm{uk} / \mathrm{view} / \mathrm{sheet} / 4531$.

Robb, Elizabeth. N.d. The Bonnie Lass o Fyvie. James Madison Carpenter Collection. AFC 1972/001, Cylinder 167 08:13. 
Robinson, Philip. 2018. Ulster-Scots: A Grammar of the Traditional Written \& Spoken Language. Belfast: Ullans Press.

Roud = List ofFolk Songsby RoudNumber. https://en.wikipedia.org/wiki/List_of_folk_songs_by_Roud_number. Royal Scots Dragoon Guards. 2008. The Lass o' Fyvie. Auld Lang Syne (Scotdisc BGS Productions, 2008) CDITV783. https://youtu.be/nQ_q1Ih6W9M.

Scots History. 2021. www.scotslanguage.com/Scots_history.

Smith, Donald. 2001. Storytelling Scotland: A Nation in Narrative. Edinburgh: Polygon.

Strachan, John. 2002. Songsfrom Aberdeenshire. Rounder Records, 1161-1835-2. https://youtu.be/b6uitPvxpNM.

\section{"POGUMNO JE JAHATI NAOKROG IN SLEDITI TABORU«: JEZIKOVNO POTOVANJE ŠKOTSKE LJUDSKE PESMI Z IRSKIM VOJAKOM SKOZI PROSTOR IN ČAS}

Članek obravnava škotsko pesem "The Bonnie Lass of Fyvie« (Lepa deklica iz Fayvija) (Roud \#545) in njeno jezikovno potovanje skozi čas in prostor. Glavni jezik pri tem je škotski, eden od treh maternih jezikov Škotske. Njegova uporaba v pesmi je afirmativno, naravno in kulturno dejanje. Preučevanje, kako se ta pesem spreminja s prenosom, je lahko širše pomembno za razumevanje, kako jezikovne spremembe vplivajo na osnovne pomene pesmi.

Pesem ima preprosto, prepričljivo zgodbo, s poudarjenim koncem, z lahkotno mikavnim ozračjem. Irski vojak, navadni dragonec, si želi lepega dekleta, ko potuje skozi njen domači kraj. Zaljubi se, ona ga zavrne, on mora zaradi ukazov oditi ter kmalu za tem zaradi strtega srca umre. Epizoda je kratka, zgodba hitro napreduje in nima veliko vsebinskih podrobnosti. Glavna zanimivost je nenavadna zgodba. Pesem uveljavlja pravico dekleta, da izbere svojo pot v ljubezni in se odloči ostati neporočena.

Članek se osredinja na majhen niz različic, ki so izbrane kot razmeroma značilne, od pesmi na letakih do posnetih nastopov pevk in pevcev, katerih jezikovno ozadje je v škotskem jeziku ali v različicah angleškega jezika. Večina jih je v škotskem jeziku: trije iz severovzhodne Škotske, med njimi so naslednji izvajalci: John Strachan (1951), The Old Blind Dogs (1992) in Iona Fyfe's (2020); dva sta iz Irske: Clancy Brothers s Tommyjem Makemom (1961) in Dubliners (1962); dva sta ameriška: Bob Dylan (1962) in Joan Baez (1963). Če jih primerjamo, se pokažejo premiki v načinu izvajanja in sprejemanja pesmi, ki kažejo, kako je njena selitev subtilno, a bistveno spremenila njen pomen.

V obravnavi »Bonnie Lass of Fyvie« avtorica ugotavlja, da lahko jezikovne spremembe med življenjsko dobo pesmi povzročijo spremembe v razumevanju vsebine pesmi, tako za tiste, ki jo izvajajo, kot za tiste, ki jo poslušajo. To lahko privede do premikov v njeni zgodbi in pomenu. Na potovanju po prostoru, času in jeziku »Bonny Lass of Fyvie« postaja vse temnejša in globlja, izgublja povezave z jezikom in kulturo, v katerih je nastala, skupaj s sporočili o pravici žensk, da se uveljavijo, in ranljivosti moških, ki so v ljubezni zavrnjeni. 
$S$ temi spremembami pesem izgubi svojo pomembnost in pomen. Pesem je najprej govorila o uveljavljanju pravic žensk in doseganju neodvisnosti od moških želja ter o ranljivosti zaljubljenih moških, v novejšem kontekstu, tj. oddaljena od izvirnih jezikov in kulture, pa se dojema kot pesem o ranljivosti žensk.

Dr. Valentina Bold, The Crichton Trust, Grierson House, info@valentinabold.org 